DOI: $10.4274 /$ tpa. 1799

\title{
Children and ethics in medicine
}

\author{
Ege University Medical Faculty, Head of the Department of History of Medicine and Ethics, Izmir, Turkey
}

Çăgatay Üstün, Nuray Demirci

\section{Summary}

Pediatric patients are included in a vulnerable group which requires more attention and sensibility in medicine. One may come across with some specific ethical problems while planning the treatment and care of the patients belonging to this group. One of the leading problems is the autonomy of the child and their decisions about themselves. However, there is no certain percept regarding these matters. Parents are directive in treatment of pediatric patients as well. In addition, ethical prevention of child patients should be taken into account by whole medical team. This paper deals with how to approach pediatric patients ethically which are vulnerable and open to abuse in the light of the related literature and case samples. (Turk Arch Ped 2013; 48: 1-6)

Key words: Child, ethics, medicine

\section{Introduction}

\section{The concepts of ethics and morals}

The word "ethics" originates from the greek word "ethos" which means character, habit and tradition. The term "ethos" was found to be appropriate and used by Aristoteles for the first time. In Turkish, the word "morals" (ahlâk) is frequently adopted in place of ethics synonymously (1). However, it is known that marked differences are present between these two terms.

If shortly described, ethics is proper and wrong behavior theory. Ethics is related to the values which a person wants to express in a certain situation (2).

The word "ahlâk" (morals) is derived from the Arabic word 'hulk' which means temper, habit and character. In Western languages (e.g. English, German), the words "morality-moral" are used to express the concept of morals. These originate from the Latin word "mos". Morals can be described as daily application of proper and wrong behavior which is expressed as ethics (3).

In the general sense, the ethical theory aims to provide a certain ethical decision process. In this process, consistency and integrity are significant. The ethical theory helps us to see a consistent way in different problems. Basically, the aim is to find an answer to the question of "What should I do?" in accordance with information, values and views (4).
It would not be wrong to state that occupations are also among the areas possesed by the ethics. We know that almost each occupation has its own specific ethical principles and these have significant role to provide a certain organization in the application processes of that occupation.

The concept of ethics, the child and ethics

In this presentation, we will try to mention the ethical subjects related to pediatrics which deals with the diagnosis and treatment of pediatric diseases.

The concept of child has a special place in terms of social position. This is also very important in terms of patient groups and appliations in medical profession.

The child is a human being who is a stranger to adults in intellectual and linguistic sense, who has inadequacy in the ability to count, classify and generalize in a logical line and who shows emotional differences. Because of these properties pediatric patients are evaluated as vulnerable groups in medicine. Therefore, this should be considered in diagnostic and therapeutical methods and medical researches which will be applied in children.

When we talk about children, we mean individuals who cover a certain area of the social life and who are kept in a seperate place from adults in terms of age. Although the age limits change by geographical and climatic properties, childhood stages cover certain time frames. These include the neonatal period $(0-2$

Address for Correspondence: Çağatay Üstün MD, Ege University Medical Faculty, Head of the Department of History of Medicine and Ethics, Izmir, Turkey Phone: +90 2323901655 Fax: +9023239021 34 E-mail: cagatay.ustun@ege.edu.tr Received: 07.02.2012 Accepted: 07.23.2012

Turkish Archives of Pediatrics, published by Galenos Publishing 
months), early childhood (15-24 months, 3-4 years), middle childhood (5-10 years) and adolescence (11-21 years) (5).

In ancient centuries, the first physician who suggested his views about the role of ethics in medicine was Hippocrates who lived in the fifth century B.C and who is defined as the father of medicine. The text of the oath which is attributed to him is still a legacy which keeps its originality and value. In the context of our subject, this text does not include any suggestions about how physicians should behave in relation to the concept of child and pediatric diseases or any relavent ethical recommendation. It is possible to attribute this to the paternal attitude which was the common and traditional medical mentality in that period (6).

Currently, it is emphasized that the basic ethical principles of medicine should be handled in a single integrity independent of the area. These principle which were presented by Beauchamp and Chidress (7) are expressed as nonmaleficence, beneficence, autonomy (respect for autonomy) and justice.

These four basic principles can be summarized as providing the patient's welfare and wellbeing, protecting autonomy, providing that the resources are shared proportionally in countries which have limited resources and not harming the patients (8).

In clinical practice, members of the medical team may follow different methods in solving ethical problems related to adult or pediatric patients. In this context, nurses also have a certain role. The most important problem in pediatric cases in medicine occur as ethical dilemmas. The reason for these problems is usually involved in the decision-making process. In clinical practice, the physicians or nurses should start to execute the ethical decisionmaking process from the time they encounter the patients. In this process, definition of the ethical problem, piecing together the factors which cause the problem, determining individual values, evaluation of the problem using the ethical principles, examination of the solution offers, adoption one of the options and application play a significant role. The DECICE example recommended by Thompson et al. (9) in the medical and nursery literature has a different point of view and includes arguments including recognition of the problem, examination in terms of ethics, thinking about the options, studying the results, deciding a behavior and evaluation of the results (PESSDS).

\section{Ethical problems in pediatric cases}

Some of the basic subjects related to pediatric ethics include the following:

- Informed consent-approval

- Decisions of families on the child in medical problems

- Ability to decide and the child

- Refusal of treatment-euythanasia

- States of children who have come to the end of their lives in intensive care units

- Status of children with hopeless prognosis

- The child in medical researches

The main ethical problems which we encounter in pediatrics include evaluation of the child as an individual, owning the right of respect, interest and protection which individuals should own, autonomy and self-decision. In fact, it is known that there are different opinions on these subjects and there is no definite comprehension. However, it is possible to give some recommendations which can be directive.

If the child is too young and inexperienced to make autonomous decisions, if it is impossible to alleviate the defects which threaten his/her autonomy because of the same reasons, the paternal intervention which is directed to prevent the child to fall into distressing situations will be definetely justified. However, if the child can make highly autonomous decisions or if he/she will be able to make decisions when the necessary assistance to alleviate the defects is given, he/she should be allowed to make his/her own decision. For example, if a child is so afraid of getting an injection as to refuse an antibiotic or rabies vaccine or antivenin which will save his/her life, it is definetely right that he is considered to be in a state in which he/she can not decide autonomously. In cases where children are able to decide by themselves, we should allow them to decide by themselves and we should also consider that the parents may have the right to decide on behalf of them (10).

In addition to informing the protector or guardian who has the authority to decide on behalf of the child about the medical picture of the child, a kind of consent should be obtained also from the child and he/she should be informed simply at an adequate level. Here, the age limit is stated to be 14-15 years. In some studies, the beginning of this age group is given as 7-8 years (11).

The 14-15 age group we mention here is related with the decision contribution and approval of the child in the relevant diagnostic and therapeutic process.

The general rules related to the position of the child in the ethical reports related to children in medicine have been presented by UNICEF after extension. According to this:

The personality and rights of each child will be cared, the rights of children will be protected meticilously in studies related with children, the age and developmental stage will also be appreciated and no story or picture which could harm the personaltiy of the child will be published even if his/her name is not used and his/her appearance is changed so that he/she can not be identified.

The parents who are primarily responsible of decisions about the child wish to make the best decision and selection on behalf of their child. However, the physican's responsibility in the decisions on behalf of the medical treatment of the child is greater and these decisions may correspond to critically distressing and problematic pictures. For example, there may be significant differences between the health problems experienced by a premature infant and a normal and term infant. The physician may need to consider the subject seperately when evaluating these two pictures in terms of the premature infant and the normal and term infant $(12,13)$.

Although it was recommended that the child's wishes and desires should be considered in diagnostic, therapeutic and 
medical rehabilitation applications or scienticif researches in the declaration of the World Medical Association related to the children's rights in healthcare, it was still emphasized that the consent should be obtained from the family or legal representative (14).

Case example: Here, an example will demonstrate the type of the ethical problem which may arise in pediatric patients. A mother brings her 7-year-old child who has upper respiratory tract infection to a physician and while evaluating the subject if the antibiotic which the child will be using should be administered as intramuscular injection or as syrup at the stage of prescription it turns out that the child dislikes syrup and is afraid of injections. What kind of a behavior will the mother and the physician decide to show?

Solution suggestion: The ethical solution suggestion in this case requires interrogating if the child has a certain ability of understanding and assessment primarly by the physician. If the child does not accept syrup or injection with his/her will, oral tablet/capsule forms may also be emphazised. If the physician prescribes an injectable antibiotic to a child who is afraid of injections in accordance with the mother's will, the problems which may arise during usage and administration should be considered. Conclusively, for a successful treatment not only the common decision of the mother and physician, but also the child's consent should be cared considering the child's age.

In adult patients, we can talk about the patient's autonomy under defined conditions. However, is there a justification to limit the autonomy in patients below the age of 18 ? In this context, the principle of respect for the patient's autonomy and the process of informed consent in pediatric patients should be discussed seperately. The most important ethical component related to informed consent in pediatric patients is the problem of competence. The importance of protecting children's rights are frequently denoted assuming that children have limited or no decision-making competence namely interrogating their competence. In terms of competence, the age and social and intellectual development of the child are important. Therefore, physicians have to obtain consent from parents to administer treatment in pediatric patients in ethical and legal terms. Similarly, it is important that the medical team is in contact with the family in the process of treatment of pediatric patients. Physicians who apply treatment without the family's consent are under risk in terms of legal terms including grown-up children. However, this risk is at the theorethical level in USA. In this country, no court has charged physicians because of not obtaining consent from families of children at the age of 15 years and above in the last 10 years. Families have not initiated any objection for medical decisions in relation to this subject (15).

However, it may be questionable if the parents will always make the most valid and right decision related to the child's disease. For example, the case in November 1998 in Saskatchewan (Canada) is related with this. When osteosarcoma (osteogenic sarcoma) was diagnosed in 13-year old patient, the cancer team reccomended chemotherapy and amputation of one leg. However, the parents stated that they refused the traditional therapy according to their Christian beliefs and wanted the treatment in a center in Mexico where other therapies were being performed. Patients father did not want the clinical team to talk with the child on this subject in the absence of the parents. The cancer team explained the family that osteosarcoma patients survived with a rate of $65 \%$ with appropriate treatment. However, there were no proved data on this subject related to other treatment methods. In this example, there is a dilemma which starts to be experienced in diagnosis and the initial process of treatment plan. Ethically, it is inevitable that a legal sanction is initiated when approaches in favour of the child are ignored. Thus, it was also true in the abovementioned case. When the medical team recognized that the family did not valued the child's preferences, they wanted that a legal way was pursued to protect the child. However, this legal process was not in favour of the child in terms of timing and cancer expanded from the leg to the lung. patient was lost in July 1999. The same condition can be experienced in the subject of refusal of blood transfusion by families who are members of Jehovah's witnesses for their children (16).

Another well known example related to the efficient role of the parents in the decision-making process is the case of "Baby Doe". Baby Doe was born in April 1982 with Down syndrome, tracheoesophageal fistula and esophagus atresia. The family did not give consent for the surgical interventions planned for this baby. The child had the chance to survive as a disabled person if the operations were performed. Although the baby's physicians litigated objecting this decision of the family, the court decided that the family had full authority. Afterwards, a bylaw was issued in 1984 and physicians were considered to be responsible of survival of newborns independent of the severity of congenital anomalies and the low chance of survival. These Works were named as Baby Doe regulations (Child Abuse Prevention and Treatment Act-1984) $(17,18,19)$.

Another ethical problem related to the authority and consent of the parents for medical procedures to be performed in children is confering to the child in the decision-making process on behalf of the child for circumscision which is a traditional approach of certain religions (Islam, Jewishness). Some accepted ethical literature texts emphasized the impropriety of the parents to be the only authority of decision for circumscision of the child and recommended that these interventions be postponed until the child reaches the age at which he/she can make a decision. The point which is whished to be emphasized here is that the parents have the authority only for diagnosis and treatment of the child's diseases and circumscision is excluded $(20,21)$.

The accepted approaches related to informed consent, parental permission and consent of the American Pediatric Academy (APP) in pediatric applications are in effect since 1976. Among these approaches, the concept of informed 
consent, the status of informed consent in terms of ethics and the concept of the right to refuse treatment, the concept of consent of the representative, parental permission and the child's consent and informed consent of the adolsecent are remarkable. The significant points in informing the parents include considering the abilty of understanding and education level of the parents, expressing the possible risks of treatment or other treatment methods, not limiting the freedom of selection between different therapies and absence of pressure.

The facts about informed consent in pediatric patients are as follows:

- All pediatric patients should be informed about their diseases and therapies in accordance with their ability to understand and their questions should be answered

- Legally, "informed consent" or "permission" should be obtained from the parents for pediatric patients

- In addition, consent should be obtained from the child who has the ability to decide

The concept of refusal of treatment is defined as absence of permanent consent for the recommended intervention to provide the well-being of the patient in the face of the patient's unwillingness (22).

There are special ways to obtain consent from the child. Accordingly, the following points should be cared:

- Absence of consent forms written in a style which can be easly understood by the child and family

- The fact that the concept of forming written informed consent form is a new concept in simple practice

- Simplification of the technique of writing as well as the content

- Preferring the daily language

- Having a form prepared in a speaking style

- Avoiding unnecessary technical language

- Avoiding long sentences

- Use of active sentence structure instead of passive sentence structure (23)

In recent years, physicians have started to recommend to terminate life in order to decrease pain and suffering of pediatric patients who stay in intensive care settings because of diseases with no possibility of cure and malign cancers especially in Western medicine. However, it is thought that this subject which is contradictive in terms of ethics should be considered with its religious dimension (24).

The concern about transformation of the duty of medicine to protect and treat patients to this kind of an insight still continues. It should not be ignored that this would be taking the easy way out and would not provide a solution.

The responsibility of ethical obligation of medicine consists of the main sturctures which can be summarized as "first, do not harm!" and "the patient's well-being is the primary consideration". We can say that these two elements are also valid for acute and transient care of children (25).

It is known that ethical problems related to infant and pediatric patients exist. These include especially the groups who need intensive care conditions and can be divided into groups including premature infants, physically disabled newborns, infants with congenital infections, newborns with respiratory problems and children with trauma. Similarly, it is inevitable that some actual ethical problems related to the diagnosis and treatment of pediatric patients will be experienced (Table 1).

Let's try to recognize the dimensions of ethical dilemmas which may be experienced by giving two examples:

Should all resources of medicine be used to provide survival of a baby who is born at the 24th gestational age with a birth weight of $500 \mathrm{~g}$ and who has spontaneous cardiac and respiratory function? If it is decided that these resources should not be used, the baby will probably die in a few hours! Is it possible that the medical team and the parents stay as a mere spectator in this condition? Generally, using all the resources of medicine dominates in such a situation and an intensive care treatment which will last for days and weeks awaits the child and parents. Usually, the outcome of this treatment which includes problems, complications, speakings, disappointments, tears and very few hope is loss of the child at the end.

A baby is born with oxygen insufficicency, is intubated, resuscicated and ventilated mechanically. After the sufferings end, all signs of Trisomy 18 which is a very severe and complicated disabling syndrome appear when the findings are pieced together. This means a survivial time limited with months and severe mental disease in patients who can reach the childhood. The diagnosis is proposed and blood sample is taken for chormosomal analysis. The child's condition improves with mechanical ventilation and the child can be extubated after a few hours. Soon, it is recognized that the child is extubated early and has to be intubated again to keep him/her alive. Should he/she be intubated again in this situation? Is it right to continue treatment as well and as long as possible until the diagnosis is confirmed with the result of the chomosomal

Table 1. Some current ethical problems related to the diagnosis and treatment of pediatric patients

Diagnosis

- Overdiagnosis made by inexperienced physicians because of fear of a malpractice case or because of pressure of the parents

-The problem of informing the parents when a disease with an unfavourable prognosis is diagnosed.

\section{Treatment}

-Treatment administered to the fetus -Limits in treatment of severely disabled children -Measures to keep children with unfavourable prognosis alive -Organ transplantation

-Refusal of a treatment by the parents and physician -Experimental treatments or controlled treatment experiences in children 
analysis? Or should the physician take the liberty to decide against keeping the child alive based on his/her clinical experience without waiting for ten days at the time the chomosomal analysis result will be obtained and probably mechanical ventilation will not be required considering such prominent findings? Would it not be more merciful to make the parents accept their child's early death instead of making them bear their child's severe disease which might last for years and making the child who has a definitely severe disability suffer? Should the family be involved in the decision-making process? (26) It should absolutely be thought intensively on such situations which involve ethical dilemmas and which worry the parents as well as the medical team in terms of solution and impatient recommendations and decisions should be avoided.

The subject of clinical researches which will be conducted in children has a distinct significance. The pediatric case should be approached cautiously, since children constitute a special group among patient groups.

Considering that clicinal studies are primarly performed in adult patients it is noted that it is not so easy to reach the data related with children. Currently, approximately $80 \%$ of the drugs used in children have been experimented only in adults and approved for treatment of the adult age group. Thus, it is clear that pediatric patients are treated according to adult experiments in daily life. For example, many antihypertensive drugs, analgesics and antidiabetic drugs are used based on adult experiments, since adequate clinical studies have not been performed in children. It is clear that this produces significant risks in terms of children. Considering that children are not "miniature" adults and have different pharmakokinetic properties and metabolisms which means they have different drug clearances, it is clear that the advers effects of the drugs we use will be more than expected (27) .

In this context, children should be protected in terms of ethical, legal and general structural problems in pediatric research studies. As the United Nations states each child has the right to get high level health care. The subjects of consent and special protection related to volunteers in medical reaseaches are mentioned in the Helsinky Decleration (1964). Legal justification related to the position of children in medical researches is included in the legal system of each country. ${ }^{*}$ In terms of the position of children in medical reseaches, volunteering should absolutely be in the foreground and consent form the parents and from the child if his/her age is appropriate should be obtained. Additionally, study methods should be prepared more meticulously in terms of ethics in unguarded groups. For example, if children with Down syndrome are to be included in a study, this study is expected not to disrupt the existing life of these children and to have the possibility to increase their quiality of life on the contrary. Again, the same attention should be paid for $\operatorname{HIV}(+)$ children and the principle of "first, do not harm" should be pursued to the greatest extent (28).
Awarenes of healthcare professionals and especially physicians and nurses in terms of child abuse and neglect, reporting of the cases to necessary positions and the active role of healthcare professionals in raising awareness of the community and families are requisites of an ethical responsibility (29).

\section{Conclusion}

The ethics has certain roles in pediatrics. This state which arises from the characteristic of pediatric patient groups should be absolutely cared. All members of the medical team should consider protection of pediatric patients in terms of ethics, since children are defenseless and open to abuse. Parents who have the authority for deciding on behalf of their children also have some responsibilities in this sense. In conclusion, parents should have a supportive role in making the child to participate in the physician's or nurse's requests in the decision-making and consent process. It should be kept in mind that the pediatric patient is an individual outside his/her certain characteristics and keeping his/her emotions and ideas in the forefront will be directive in medical decisions which will be made on behalf of him/her.

\section{References}

1. Cevizci A. Etiğe giriş. İstanbul: Paradigma yayınları, 2002: 3.

2. Billington R. Felsefeyi Yaşamak, (Çev. A. Yılmaz). İstanbul: Ayrıntı Yayınları, 1997: 45-46.

3. Seyyar A. Ahlâk terimleri. İstanbul: Beta Basım, 2003: 10.

4. Shannon TA. Bioethics. Fourth Edition. Paulist Press 1993: 3.

5. Le T, Lam W, Rabizadeh S, Schroeder A, Vera K. First Aid for the pediatric boards. The McGraw-Hill Companies Inc 2006: 500.

6. Üstün Ç. Tıp sanatının ustası Hippokrates. Ege Üniversitesi Tıp Fakültesi Yayınları 156, İzmir 2003: 39-42.

7. Beauchamp TL, Childress JF. Principles of biomedical ethics. Fifth edition. Oxford University Press 2001: 12.

8. Sarnaik AP, Daphtary K, Sarnaik AA. Ethical Issues in pediatric Intensive care in developing countries: combining western technology and eastern wisdom. Indian J Pediatr 2005; 72: 339-340.

9. Avcı K. Pediatri alanında hemşirelerin etik sorunların çözümüne yönelik yaklaşımlarının incelenmesi. Hacettepe Üniversitesi Sağlık Bilimleri Enstitüsü, Yüksek Lisans Tezi, Ankara 2007: 15-16.

10. Harris J. Hayatın değeri-tıp etiğine giriş, (Çev. S. Sertabiboğlu). İstanbul: Ayrıntı Yayınları, 1998: 291-293.

11. Angelos P. Ethical Issues in cancer patient care. Second edition. Springer Science+Business Media, 2008: 95-96.

12. Cassidy RC, Fleischman AR. Pediatric ethics-from principles to practice. Harwood Academic Publishers 1996: 44-45.

13. Özyalçın S, Dinçer S. Çocuklarda ağrı ve etik. Terminal dönemde çocuk: etik sorunlar. İstanbul: Nobel Tıp Kitabevleri, 2006: 152-153.

14. World Medical Association, Decleration of Ottawa on the Right of the Child to Helath Care-50. World Medical Assembly, Canada, 1998-60. World Medical Assembly, India, 2009. http://www.wma.net/ en/30publications/10policies/c4/ (Son erişim tarihi: 22.08.2012).

15. Aydın E. Çocuklarda aydınlatılmış onam sorunu. Çocuk Sağlığı ve Hastalıkları Dergisi 2003; 46: 148-152.

16. Yeo M, Moorhouse A, Khan P, Rodney P. Concepts and cases in nursing ethics (Third edition). Peterborough: Broadview Pres 2010: 117-118.

17. Lang GC. Baby doe-a medical ethics issue. West J Med 1985; 142: 837-841. 
18. Lo B. Resolving ethical dilemmas-a guide for clinicians. Second edition. Philadelphia: Lippincott williams\&wilkins 2000: 291-292.

19. Frankel LR, Goldworth A, Rorty MV, Silverman WA. Ethical dilemmas in pediatrics. Cambridge University Press 2005: 41-42.

20. American academy of pediatrics committee on bioethics, informed consent, parental permission, and assent in pediatric practice. Pediatrics 1995; 95: 314-317.

21. Seeking patients consent: the ethical considerations. London, General Medical Council 1998.

22. De Lourdes Levy M, Larcher V, Kurz R. Ethics working group of the confederation of european specialists in paediatrics (CESP). Informed consent/assent in children. Statement of the Ethics working group of the confederation of european specialists in paediatrics (CESP). Eur $\mathrm{J}$ Pediatr 2003; 162: 629-633.

23. Green JB, Duncan RE, Barnes GL, Oberklaid F. Putting the 'informed' into 'consent': a matter of plain language. J Paediat. Child Health 2003; 39: 700-703.
24. Miller RB. Children ethics and modern medicine. Indiana University Press 2003:25-26.

25. http://www.practicalbioethics.org/FileUploads/PB_Peds_May2008.pdf (Son erişim tarihi: 08.08.2011).

26. v. Engelhardt D. Tıbbın gündelik yaşamında etik, (Çev. Arın Namal). İkinci baskı. İstanbul: Nobel Tıp Kitabevleri, 2001: 198-203.

27. Kavaklı K. Çocuklar üzerinde yapılan klinik araştırmalarda standartlar. İçinde: Akan H. (yazar). Klinik araştırmalar kitabı. Ankara: Bilimsel Tıp Yayınevi, 2010: 343.

28. Burgess-Pinto E, Miller C, Ritch C. Protection of children: ethical, legal and structural issues in pediatric research, ethics in the hew age. John Dossetor Health Ethics Centre 1999: 2: 57-89.

29. Kocaer Ü. Hekim ve hemşirelerin çocuk istismarı ve inmaline yönelik farkındalık düzeyleri. Marmara Üniversitesi Sağlık Bilimleri Enstitüsü Yüksek Lisans Tezi, İstanbul 2006: 54-55. 